\title{
Pending Legislative Restrictions on the Use of Agricultural Chemicals on Tobacco*
}

\author{
by F. E. Guthrie \\ North Carolina State University, School of Agriculture and Life Sciences, \\ Department of Entomology, Raleigh, N. C., USA
}

The international trade of tobacco probably involves more movement in and among countries than any other agricultural commodity. Leaf tobacco used to prepare the blend for a particular brand of cigarettes in England may have been purchased from Rhodesia, Canada, Turkey, Iran, Dominican Republic, Philippine Islands, and India. Following manufacture, one day's production of that brand could ultimately be offered on the retail market in the United States, Sweden, West Germany, Australia, Taiwan, Brazil, Hong Kong, and Singapore. Or, the unmanufactured or manufactured product may have been purchased in any of these countries and ultimately sold to another country. It is obvious that this type of trade is possible only if there are no restrictions on purchase of tobacco by any country involved in this extensive international enterprise or if all countries comply with the restrictions made by one country which manufactures or imports large quantities of tobacco. For example, assignment of tolerances to pesticide residues on tobacco by any major country effectively places worldwide tolerances on this product.

Since publication of Silent Spring (8) in 1962, it became only a matter of time before pesticides used on tobacco would be more carefully scrutinized by the United States and other governments. The informal action to restrict the use of chlorinated hydrocarbons on tobacco by the Entomology Section of the U. S. Tobacco Workers' Conference in 1964 (2) was ultimately extended to formal establishment of pesticide tolerance limits on tobacco by the West German Government (3).

To date, West Germany, Jugoslavia, and Sweden are the only countries to enact legislation establishing pesticide tolerance limits on tobacco sold within their boundaries. The West German law is by far the most comprehensive, covering all manufactured tobacco and a number of pesticides, and it seems likely to become

\footnotetext{
* Presented at the CORESTA (General Assembly)/26th TCRC Joint Conference held in Williamsburg, Va., USA, in October 1972.

Partial funds for support of this work was provided by PHS grant ES-00044 from the Institute of Environmental Health Sciences.

Paper No. 3938 of the Journal Series of the North Carolina State University Agricultural Experiment Station, Raleigh, North Carolina.

The author also wishes to adrnowledge the appreciable help of $\mathrm{J}$. J. Domanski, W. H. Dorough, and K. H. Weber who provided critical unpublished information and valuable advice concerning this manuscript.
}

effective on January 1,1978 . Several years ago, Jugoslavia enacted legislation which limited certain dithiocarbamate fungicides to $5 \mathrm{ppm}$ on tobacco. Recently, Sweden enacted legislation to ascribe tolerances on snuff and hewing tobacco but withheld regulations on other tobacco products. It seems likely that a number of other countries, particularly members of the European Community, will enact legislation similar to that in West Germany in the near future.

The precise details of the West German law have not been finalized, and some changes seem likely. However, the tolerances for the major pesticides used on tobacco probably will be similar to those listed in Table $I$. A number of relatively minor pesticides and fumigants have been omitted from the table because they seem unlikely to occur in high enough average amounts on the world market to contribute significantly to residue problems when one considers the blending operations presently common in tobacco manufacture.

In considering legislative restrictions on tobacco, two types of actions were considered for this discussion.

I. Restrictions on import of tobacco caused by assignment of residue tolerance laws by a governmental agency.

2. Restrictions on grower use of pesticides by governmental or commercial interests to protect an export market.

Table 1. Proposed, but tentative, West German tolerances (ppm) for commonly used peaticldes on tobacco (law likely to become effectlve January 1,1978 ).

\begin{tabular}{lcll}
\hline Compound & Tolerance & Compound & Tolerance \\
\hline Azinphosmethyl & 0.4 & Endosulfan & 0.5 \\
Carbaryl & 2.5 & Lindane & 2.0 \\
DDT components & 0.1 & Malathlon & 3.0 \\
Diazinon & 0.3 & & \\
Disyston & 0.4 & Parathion & 0.5 \\
Dimethoate & 0.6 & Phorate & 0.01 \\
Dinocap & 1.0 & Phosphamidon & 0.15 \\
Dithiocarbamate fungicides & 3.0 & Toxaphene & 0.1 \\
\hline
\end{tabular}

Compounds completely forbidden (limit of detection) include arsenicals, carbon disulfide, carbon tetrachlorlde, chlordane, dieldrin, endrin and heptactior. 
Restrictions on imported tobacco seem likely to be made on the commercial product, either that produced from imported, unmanufactured tobacco for sale in that country or tobacco products made in other countries and exported to the country with the tolerance law. This type of restriction seems unlikely to be placed directly on unmanufactured tobacco by the government, but it requires the tobacco manufacturer or seller to have adequate residue information on the tobacco he imports (or obtains domestically). The West German legislation is typical of this kind of action.

Restrictions on the use of pesticides within a country which itself does not have a tolerance law are largely enacted to permit export of unmanufactured tobacco to a country which has placed residue tolerances on tobacco. In a survey recently conducted to investigate restrictions, a large number of countries contacted indicated that pesticides are restricted to some extent [(5) and numerous personal communications to the author]. Restrictions vary from mere warnings to growers that overuse of pesticides may threaten sales to blocking the sale of tobacco with excessive residue. The decision to take the latter action is based on analytical surveys of tobacco by governmental organizations. The present status of efforts to reduce pesticide residues on tobacco varies as indicated by the following examples:

Angola: No tolerance laws. To date no governmental action has taken place although tobacco interests have been informed of the West German law.

Argentina: No tolerance laws. The Ministry of Agriculture attempts to restrict use of dhlorinated hydrocarbon insecticides and provides a list of approved pesticides to the growers.

Austria: No tolerance laws. A bill in preparation is modeled after the West German law.

Belgium: No tolerance laws. Government laboratories and tobacco interests are well informed of West German law. Pesticide residues on imported and domestic tobaccos are extensively monitored.

Brazil: No tolerance laws. Use of certain dilorinated hydrocarbons is forbidden by the Ministry of Agriculture but enforcement is irregular.

Bulgaria: No tolerance laws. The government forbids use of organochlorines on tobacco and provides growers with an approved list of pesticides.

Canada: No tolerance laws. The Ontario Pesticide Act forbids use of certain chemicals, especially chlorinated hydrocarbon insecticides. The use of maleic hydrazide is permitted but growers must mark such tobacco at sales.

Denmark: No tolerance laws. Chlorinated hydrocarbons are forbidden for use on tobacco, and legislation is pending to forbid sales of those compounds in the country.

East Germany: No tolerance laws. No restrictions under consideration. The tobacco interests have begun analyses of domestic and imported tobacco.
England: No tolerance laws. No governmental restrictions are expected, but tobacco interests voluntarily exercise authority to restrict purchase of tobacco with undesirably excessive pesticide residues. Imported, unmanufactured tobacco is carefully monitored to determine the extent of residues from all sources.

France: No tolerance laws. Governmental restrictions are under consideration. Tobacco interests are aware of pesticide problems (primarily dithiocarbamate fungicides) on domestic tobacco and chlorinated hydrocarbons on imported tobacco. Both lindane and DDT are restricted from use on tobacco grown and stored in France.

Greece: No tolerance laws. The National Tobacco Board and the Greek Tobacco Ministry prohibit use of some chemicals and limit the use of others to a CORESTA-approved list of pesticides. They are considering enactments to prevent import of certain chlorinated hydrocarbons.

Hungary: No tolerance laws. The use of certain chlorinated hydrocarbons is forbidden, and a waiting period between application and harvest has been suggested where it becomes necessary to use dithiocarbamate fungicides.

India: No tolerance laws. No formal governmental restrictions have been enacted, but a well-informed extension program provides growers with information about approved chemicals and warns against the use of unacceptable chemicals for tobacco likely to be exported.

Iran: No tolerance laws. There are no governmental restrictions at present although they are under consideration.

Italy: No tolerance laws. The tobacco interests are taking drastic steps to subscribe to the West German legislation except for dithiocarbamate fungicides. No formal legislation has been enacted.

Japan: No tolerance laws. The Japanese Tobacco Monopoly forbids use of certain dilorinated hydrocarbons. The recommended list of pesticides includes maleic hydrazide and dithiocarbamate fungicides.

Jugoslavia: A tolerance of $5 \mathrm{ppm}$ for dithiocarbamate fungicides is in effect; the Ministry forbids the use of certain dilorinated hydrocarbons.

Lebanon: No tolerance laws. The Tobacco Board provides CORESTA-approved pesticides free to growers.

Mexico: No tolerance laws. The use of certain chlorinated hydrocarbons is not permitted. Attempts are being made to follow U. S. practices on tobacco residues.

Netherlands: No tolerance laws. No formal restrictions have been enacted, but tobacco interests maintain extensive survey of imports.

Norway: No tolerance laws. There are no restrictions at present, but legislation similar to West Germany is under consideration. 
Philtppines: No tolerance laws. Tobacco interests are taking steps to forbid use of DDT because the 1971 crop had residues in excess of West German tolerances.

Poland: No tolerance laws. The Central Laboratory of the Tobacco Industry and the Central Institute of Standardization are considering regulations. Use of chlorinated hydrocarbons is presently forbidden on tobacco.

Paraguay: No tolerance laws. The Ministry of Agriculture attemps to restrict organochlorines on domestic tobacco, but these pesticides are available in open commerce.

Republic of China (Taiwan): No tolerance laws. Restrictions on chlorinated hydrocarbons are attempted by tobacco interests, but effective legislation has not been enacted.

Rhodesia: No tolerance laws. The Tobacco Research Board, acting for the Ministry of Agriculture, monitors tobacco during sales and prohibits sale of tobacco treated with restricted pesticides. Extensive surveys have been made for several years and Rhodesian tobacco generally complies with the West German law.

South Africa: No tolerance laws. Tobacco interests restrict the use of chlorinated hydrocarbons and other pesticides. Growers are provided with a list of approved chemicals and an application schedule that should be followed to avoid undesirable residues. Surveys of residues have been made on domestic tobacco for several years.

Sweden: Tolerance laws have been restricted to snuff and chewing tobacco only; extensive analyses of all tobacco purdased have been routine for the past several years, and future purchases will be based on compliance with the West German law.

Switzerland: No tolerance laws. The use of chlorinated hydrocarbons on domestic tobacco is restricted. Stringent limitations on pesticide residues on imported tobacco is under consideration, and tobacco has been monitored for several years.

Thailand: No tolerance laws. The growers have been informed of actions by West Germany. The availability of DDT in the World Health Organization (WHO) mosquito control programs is causing problems in reducing residues.

Turkey: No tolerance laws. The Ministry of Agriculture recommends a list of pesticides for pest control. Attempts are made to restrict the use of chlorinated hydrocarbons on field tobacco but compliance is voluntary.

United Arab Republic: No tolerance laws. The growers have been informed of the recent restrictions placed on tobacco by the West German government.

United Nations: Neither the WHO nor Food and Agricultural Organization (FAO) is contemplating recommendation for tolerances or restrictions of pesticides on tobacco because tobacco is not classified as a food and has not-been under the consideration of these expert study groups.

United States: No tolerance laws. The government does not register certain chlorinated hydrocarbons for use on tobacco, but some of these chemicals are available in commerce. The sale of tobacco at a guaranteed government price is not permitted unless the grower signs a statement that restricted pesticides have not been used. The Stabilization Board makes limited surveys of chlorinated hydrocarbons to insure that growers comply, and support prices are not granted if the tobacco contains over $3 \mathrm{ppm}$. A pilot, government-sponsored Pest Management Program provides growers in several study areas with information on insect infestations and recommends more restrictive use of pesticides to these growers. These studies have shown that approximately $50 \%$ of the insecticides used on tobacco is not justified on the basis of estimated potential damage by insects.

West Germany: Tolerances on residues of pesticides on tobacco in commerce have been established.

It seems appropriate at this point to examine the effect that the pending West German regulation and the resulting actions made by the international tobacco interests have had on residues of pesticides. The events leading to this situation were summarized in 1968 (16). The data reported in the present discussion may seem to place too much emphasis on U. S. tobacco, but there are a number of reasons for this:

1. There have been more comprehensive studies made, and more data published, in the U. S. concerning residues on tobacco during the past 15 years.

2. Widespread use of pesticides has occurred throughout most of the U. S. tobacco-producing belts.

3. Approximately one-third of U. S. unmanufactured tobaccos are found in the export market. In addition, U. S. manufactured tobacco is extensively imported into many foreign countries.

\section{Pesticide Residues on Tobacco Products}

The data summarized in Table 2 indicate that there has been little dhange in the residues of DDT on commercial cigarettes and other tobacco products since the recent concern about residues. The 1972 survey of cigarettes is from a limited number of brands and may not necessarily indicate a true decline. DDT components on other manufactured tobacco products also have not shown any drastic decline during the past several years. Residues of endrin have decreased on cigarettes, but they are still well above proposed tolerance levels on other types of tobacco. Endosulfan and dieldrin residues appear to be below proposed tolerances on all types of tobacco tested, but toxaphene residues are well above proposed tolerances. Residues of parathion on cigars are below tolerances proposed. Limited surveys also indicate that malathion and disyston. residues are below proposed tolerances. 
Table 2. Ineecticlde realdues on manufactured American tobacco.

\begin{tabular}{|c|c|c|c|c|c|c|c|c|c|c|c|c|c|c|c|c|}
\hline \multirow{2}{*}{$\begin{array}{l}\text { Tobacco } \\
\text { product }\end{array}$} & \multicolumn{9}{|c|}{ ppm, DDT-TDE components* } & \multicolumn{7}{|c|}{ ppm, other insecticides** } \\
\hline & 1956 & 1960 & 1962 & 1965 & 1968 & 1969 & 1970 & 1971 & 1972 & $\begin{array}{l}\text { Mala- } \\
\text { thion }\end{array}$ & $\begin{array}{l}\text { Disy- } \\
\text { ston }\end{array}$ & Endrin & $\begin{array}{l}\text { Endo- } \\
\text { sulfan }\end{array}$ & $\begin{array}{l}\text { Toxa- } \\
\text { phene }\end{array}$ & $\begin{array}{l}\text { Para- } \\
\text { thion }\end{array}$ & $\begin{array}{l}\text { Diel- } \\
\text { drin }\end{array}$ \\
\hline Cigarettes & 12 & 一 & 22 & 32 & 32 & 37 & 36 & 41 & 27 & - & 一 & $0+$ & $0.4+$ & $3.4+$ & - & $0+$ \\
\hline Cigars & - & 17 & 44 & 12 & - & 17 & - & 16 & 17 & $0+$ & $0+$ & $0.37+$ & $0.44+$ & $0.77+$ & $0.06+$ & - \\
\hline Pipe & - & $\mathbf{5}$ & 15 & - & - & 18 & $一$ & 22 & - & - & - & $0.13++$ & $<0.2++$ & $1.62++$ & - & - \\
\hline Chewing & - & 4 & - & - & - & 5 & - & 13 & - & - & - & $0.14++$ & $0.25++$ & $1.42++$ & - & - \\
\hline Snuff & - & 5 & 20 & - & - & 18 & - & 16 & - & - & - & $0.18++$ & $<0.20$ & $1.22++$ & - & - \\
\hline
\end{tabular}

\footnotetext{
- Results for DDT components (lsomers plus de-HCl) from 1968-1971 corrected for equal extraction. Other data may not be directly comparable $(6,12,13,15,16,20)$.

** References 12, 13, 15, 20.

+1972 data.

++1971 data.
}

\section{Pesticide Residues on Unmanufactured Tobacco}

A number of surveys have been made on pesticide residues on tobacco at auction sales and tobacco in storage. The data shown in Table 3 are from a study on burley tobacco which parallels results of several other investigations on flue-cured and other types of tobacco taken during warehouse sales. DDT components remained at high levels through 1969 and then dramatically decreased on burley, flue-cured, and most other types of U. S. tobacco. Although levels are some $1 / 10$ to $1 / 20$ of those of several years ago, they are still well above tolerances presently proposed in the West German law. Endrin residues, well below early 1960 levels, vary considerably among the belts. Although this survey on burley tobacco (Table 3) indicates a small residue of endrin, results from a number of other surveys indicate that endrin residues are more frequently at background levels. Dieldrin residues are slightly above the projected tolerance on burley and certain other air-cured types, but these residues are less frequently detected on flue-cured tobacco. Endosulfan residues have increased on burley tobacco in recent years and average $1-3 \mathrm{ppm}$ in the flue-cured areas. Toxaphene, whose use has been discouraged since 1955, continues to plague the indu- stry. Although the average residue figures for a number of belts are below detection, a significant number of samples show toxaphene residues in excess of the proposed tolerance. Phosphate insecticides were not detected in one survey.

Two other recently reported surveys are important to this discussion. As seen in Table 4, residues of insecticides are in general agreement with the results previously mentioned. One study includes data for carbaryl residues which are $1.5 \mathrm{ppm}$, well below the proposed tolerance. In the survey made in Florida, a high-use area for parathion, the average parathion residue was $0.3 \mathrm{ppm}$ (below proposed tolerances) and random samples from one warehouse averaged nearly $2 \mathrm{ppm}$. The report for residues of maleic hydrazide is in general agreement with a large volume of published (7) and unpublished data and these residues are felt to be generally representative of flue-cured tobacco throughout the U. S. (use decreasing slightly as one moves north from the Florida-Georgia belts).

\section{Residues of Pesticides on Tobacco from other Countries}

Although there have been no extensive surveys reported on tobacco from other countries, there are some data available (Table 5). It must be stressed that

Table 3. Pesticlde residues on burley tobacco in storage (ppm)*.

\begin{tabular}{|c|c|c|c|c|c|c|c|c|c|}
\hline & 1963 & 1964 & 1965 & 1966 & 1967 & 1968 & 1969 & 1970 & 1971 \\
\hline DDT components & 12.6 & 23.5 & 22.0 & 65.0 & 50.4 & 45.3 & 62.0 & 3.8 & 3.0 \\
\hline Endosulfan & N.D. & N.D: & N.D. & N.D. & N.D. & N.D. & 0.87 & 3.1 & 4.5 \\
\hline Dieldrin & 0.22 & 0.36 & 0.34 & 0.68 & 0.62 & 0.65 & 1.09 & 0.25 & 0.11 \\
\hline Endrin & 0.61 & 0.21 & 0.02 & 0.02 & N.D. & 0.10 & 0.04 & N.D. & 0.2 \\
\hline $\begin{array}{l}\text { Toxaphene } \\
\text { Chlordane }\end{array}$ & 0.81 & N.D. & 1.1 & 2.7 & N.D. & N.D. & 2.3 & -** & $\begin{array}{l}\text { N.D. } \\
0.05\end{array}$ \\
\hline Malathion & & & & & & & & N.D.+ & \\
\hline Diazinon & & & & & & & & N.D.t & \\
\hline Disulfoton & & & & & & & & N.D.+ & \\
\hline Parathion & & & & & & & & N.D.t & \\
\hline
\end{tabular}

- Data from Gibson and Dorough (15). Similar results in other studies (11) on all types of tobacco.

** N. D. In burley, $<1$ in flue, and up to 8 in certaln air-cured.

+ Averages of composites from 70 warehouses (flue-cured). 
Table 4. Residues of pesticides (ppm) found on flue-cured auction markets, 1971.

\begin{tabular}{|c|c|c|c|c|c|c|}
\hline Market & DDT component & Carbaryl & Parathion & Endosulfan & Toxaphene & Maleic hydrazide \\
\hline Georgia* & 1.3 & 1.5 & 0.06 & 2.9 & 1.9 & 49 \\
\hline Florida** & 0.9 & & 0.30 & 0.1 & - & \\
\hline
\end{tabular}

- French (14).

*. Strictland and Whitley (21).

these data are incomplete, not necessarily representative, and are included merely to illustrate the problem. The magnitude of the DDT problem in these areas is generally less than in the U. S., but the residues are still above projected tolerances in most cases. Problems with residues of insecticides other than those shown in Table 5 are difficult to assess; however, such problems appear to be minor except in a few areas which probably contribute but a small share to the total production of tobacco.

The use of dithiocarbamate fungicide for blue mold control on full-grown tobacco has been most evident in Europe but may become more widespread since various fungus diseases occur in field-planted tobacco in other tobacco-producing areas of the world. When required for field treatment, fungicide residues are of necessity well above $50 \mathrm{ppm}$ and often exceed $500 \mathrm{ppm}$.

Maleic hydrazide is used for sucker control in a number of countries, but no recently published data on residues of this chemical are known outside the U. S.

\section{Residues from Recently Introduced Pesticides on}

Tobacco

Several insecticides have been introduced in recent years and are likely to become well-accepted by growers. Although there is no published information concerning the residues on commercial tobacco, some experimental tobaccos have been examined for methomyl and azodrin (1, 17, 22). It would appear that residues of these compounds would not become a problem on flue-cured tobacco but might cause minor problems on air-cured types when heavy use becomes necessary. Degradation in smoke reduces their potential contribution to the residue problem.

\section{Assignment of Responsibility of Adherence to Tolerances}

Within the tobacco industry, which organizational components will determine whether the product to be manufactured, or already manuffactured, will meet the tolerances to be enforced by the country with the tolerance law?

Unmanufactured Tobacco: With unmanufactured tobacco it seems likely that the manufacturer of the product will assume responsibility for adherence to tolerances. He will undoubtedly attempt to place maximum responsibility for residues on the individual or company selling the leaf. However the manufacturer of the tobacco product cannot assume that the tobacco he purchases meets the required residue stan-

Table 5. Sample pestlcldes residue data reported from non-U.S. tobacco, 1969-1972. (Data from personal communlcatlons from governmental agencles In each country.)

\begin{tabular}{|c|c|c|c|c|c|c|c|c|}
\hline \multirow{2}{*}{ Country } & \multicolumn{8}{|c|}{ ppm on cured, unmanufactured tobacco } \\
\hline & DDT + & Lindane & Endosulfan & Dieldrin & Heptachlor & Endrin & Phosphates** & $\begin{array}{c}\text { Dithiocar- } \\
\text { bamates }\end{array}$ \\
\hline Austrla & - & - & - & - & - & - & - & $>40$ \\
\hline Belgium & $10^{*}$ & - & - & - & - & $0.1^{*}$ & $<0.5$ & $>50$ \\
\hline Canada & $<1$ & 0.1 & - & $<0.1$ & - & $<0.1$ & - & - \\
\hline E. Germany & 0.8 & - & - & - & - & 0.1 & - & - \\
\hline France & $<1$ & $<0.03$ & - & - & - & - & $<0.5$ & $80^{*}$ \\
\hline Greece & $>7$ & 0.3 & 0.3 & 0.5 & $<0.1$ & - & - & $>50$ \\
\hline \multicolumn{9}{|c|}{ Oriental purchases: } \\
\hline (Belglum) & $>4.0$ & $>0.3$ & - & 0.2 & $>0.1$ & $<0.01$ & $<0.5$ & $>100$ \\
\hline (French) & 2.0 & 0.9 & - & - & - & - & - & - \\
\hline Paraguay & - & - & - & - & - & - & - & $>100$ \\
\hline Rhodesia & 0.4 & - & - & 0.01 & - & - & $-\mathbf{a}$ & - \\
\hline So. Africa & - & - & $<0.05$ & - & - & - & $<0.5$ & - \\
\hline Switzerland & $<0.1$ & 0.1 & - & - & - & - & - & - \\
\hline
\end{tabular}

- Commercial products.

*- Includes parathion, dlazinon, dimethoate, malathlon but not necessarily all from each country.

a Menazon found up to 5 ppm but Azodrin, demeton, and dimethoate residues were below limits of detection. 
Table 6. Hypothetlcal clgarette biended from 1971 commerclal tobecco (from 10 sources on which at least limited realdue data were avallable).

\begin{tabular}{l|c|c|c|c|c|c}
\hline & \multicolumn{6}{|c}{ ppm reported from 1971 survey data } \\
Area & $\begin{array}{l}\text { \% of } \\
\text { blend }\end{array}$ & DDT & $\begin{array}{c}\text { Diel- } \\
\text { drin }\end{array}$ & $\begin{array}{c}\text { Endo- } \\
\text { sulfan }\end{array}$ & $\begin{array}{c}\text { Toxa- } \\
\text { phene }\end{array}$ & Endrin \\
\hline Georgia flue - & 10 & 1.3 & $?$ & 2.9 & 1.9 & $?$ \\
N.C. old belt flue - & 10 & 1.4 & N.D. & 0.7 & 0.2 & N.D. \\
Tenn. dark air - & 10 & 13.3 & 0.4 & 4.8 & $?$ & 0.12 \\
Rhodesla flue - & 10 & 0.4 & N.D. & $?$ & $?$ & $?$ \\
Oriental air - & 10 & 4.0 & 0.2 & $?$ & $?$ & $?$ \\
Canada flue - & 10 & 1.4 & 0.14 & $?$ & $?$ & 0.05 \\
Kentucky burley & 20 & 3.0 & 0.11 & 4.5 & N.D. & 0.2 \\
(duplicated) & - & 3.0 & 0.11 & 4.5 & N.D. & 0.2 \\
Greece air - & 10 & 7.0 & 0.50 & 0.3 & $?$ & $?$ \\
E. German flue - & 10 & 0.8 & $?$ & $?$ & $?$ & 0.1 \\
\hline Avg. & & 3.6 & 0.15 & 1.8 & 0.21 & 0.07 \\
Pending tolerance & & 0.1 & $<0.05$ & 0.5 & $0.10<0.05$ \\
\hline
\end{tabular}

dards because he, not the seller of the raw tobacco, must meet the requirements of the tolerance laws. At first blush this seems like an overwhelming problem for there are at least 20 pesticides in common use on tobacco. Suitably automated analyses of multiple pesticide residues would increase the price at least $\$ 150-200$ per hogshead. However, it must be remembered that the use of pesticides varies greatly among countries, and many of the pesticides would only cause problems under rather unusual conditions. As the tobacco interests become familiar with the residues to be expected from various areas, the proper pesticides can be monitored for particular blends. The problem becomes one of averages, because the blending process can be expected to dilute high residue lots by a factor of ten or more. This does not mean there are not problems, especially with respect to the very restrictive laws that are presently pending. Table 6 illustrates the problems on a hypothetical blend made from 1971 commercial purchases whose residue content was fairly well known. It is obvious that the presently pending legislation is too restrictive for cigarettes blended from ten such purchases.

The change to phosphate and carbamate insecticides may permit flue-cured tobaccos to meet tolerance standards by 1978. However, the solution to the problem is not so obvious when products are made from aircured tobaccos in heavy pest areas where pesticides must be used during the harvest season. The main international effort on elimination of residue has been on chlorinated hydrocarbons on cigarettes, and some attention must be directed to possible residues of other insecticides on cigars, snuff, pipe, and chewing tobacco which are largely manufactured from air-cured leaves.

Tobacco Products: This problem is not concerned with the manufacturer producing products in the country which has the tolerance law but with the foreign manufacturer who exports finished products into a country with a tolerance law. Such trade may be direct or it may be handled by brokers. The sales, however, will ultimately be at the retail store. The manager of the West German tobacco store, or supermarket, who handles foreign tobacco products is probably not even aware of the problem. The details of responsibility are somewhat vague. Perhaps the foreign manufacturer will have to guarantee that his product will meet the tolerances. Or, the country with the residue tolerance limits may monitor and seize foreign products as they enter the country. As the law presently reads, the tolerance is on the commercial product, and the West German tobacco shop owner seems unlikely to know about this law until his first foreign products are seized.

\section{Immediate Problems}

Although tremendous strides have been made in recent years, there are some major problems still facing the industry as a result of the pending tolerance legislation, some seemingly unsurmountable within a few years.

Dithiocarbamate fungicides.

Maleic hydrazide.

Any pesticide (including phosphate and carbamate types) with tolerances below $2 \mathrm{ppm}$ that gains extensive use on air-cured types in high pest areas unless greater emphasis on degradation during smoking is considered by agencies ascribing tolerance limits.

Chlorinated hydrocarbons.

The dithiocarbamate fungicide and maleic hydrazide problems have been complicated by recent concern over ethylene thiourea (ETU) as a possible contaminant of dithiocarbamates (4) and phenyl hydrazines as possible degradation products of maleic hydrazide (10). The latter concern is in controversy (19). Recent work by Carugno and Fedrizzi has shown that $99 \%$ of zineb disappears during smoking (9) but ETU residues were not determined. Unpublished information on maleic hydrazide appears to have reassured the West German authorities sufficiently enough that maleic hydrazide was recently taken off the restricted list of pesticides. Both compounds would probably require tolerance limits of $30-50 \mathrm{ppm}$ to permit their continued widespread use on tobacco.

The question of "degradable" insecticides, such as phosphates and carbamates, on air-cured tobacco has already been discussed. The problem is reiterated at this point mainly because it is not under adequate investigation. One tends to consider the tobacco industry as synonymous with "cigarettes" but other products are an important part of the total.

The problem with chlorinated hydrocarbons is due to limited use of endosulfan on foliage, minor "illegal" use or drift of toxaphene on foliage, and the problem of soil residues of DDT, dieldrin and other cyclodiene 
Table 7. Realdues (ppm) found on non pesticlde-treated flue-cured tobacco grown In solls containing pesticides*.

\begin{tabular}{c|c|c|c|c}
\hline Farm & $\begin{array}{c}\text { DDT } \\
\text { components }\end{array}$ & Dleldrin & Endrin & Dursban \\
\hline A & 0.8 & .09 & .13 & - \\
B & 2.3 & .07 & .05 & - \\
C & 1.4 & .14 & .05 & - \\
D & 1.2 & .05 & .22 & - \\
E & 1.7 & .04 & .06 & - \\
F & 1.6 & .06 & .06 & N.D. \\
\hline
\end{tabular}

" Vickery (23).

insecticides. Nearly every tobacco field in the world has residues of chlorinated hydrocarbons in the soil, either directly from efforts to control soil insect pests or indirectly from treatment of tobacco foliage. Leaves of tobacco plants grown in these soils are likely to have amounts of pesticides in excess of tolerances even where the pesticide is not applied directly to the leaves. The extremely stringent tolerance limits for some chlorinated hydrocarbons create an almost impossible situation as is well illustrated in Table 7. In this preliminary evaluation nearly every sample was well over the tolerance limit although insecticides were not applied directly to tobacco. It is suggested that the soil residues are transferred to the leaves by systemic action, by splashing of soil onto leaves by rain, by soil dust, and by volitalization from soil and condensation on leaves. Unless the present legislation is changed to a more realistic tolerance, it would appear to the writer that tobacco grown on such contaminated soil could not be sold in West Germany after January 1, 1978.

Two environmental problems have occurred since the Stockholm CORESTA Conference that will be of interest. One concerns the total environment. There has been evidence in Sweden (18) that the main source of DDT components in rivers near congested areas is from the DDT in cigarette butts. In a country where DDT is banned, no other explanation for continued detection of DDT in water was suggested although one immediately questions the contribution of polychlorinated biphenyls (PCB) to this contamination problem. It will be interesting to hear from this problem when the 1970 tobaccos become common in cigarettes.

The second problem concerns human safety. Tobacco is extensively handled by human labor during culture ( 150,000 persons each season in the U.S. alone). When such tobacco has been recently treated with pesticides there may be hazards to harvesters. During the years of heavy use of chlorinated hydrocarbons this was not identified as a problem because the acute dermal toxicities of these compounds were not high. However, the change to phosphates and carbamates has introduced compounds with much greater dermal hazards. In the United States, minimum re-entry periods between application and harvest are being established to protect the worker - - "wait five days after application of parathion before entering fields", for example.

\section{SUMMARY}

Much progress has been made toward decreasing residue levels of a number of pesticides on tobacco in recent years. However, important problems have not been resolved. Foremost among these are necessary changes in pending tolerance legislation. CORESTA and other tobacco interests in Europe and North America have responsibly defined the problem areas for the officials charged with legislative action. With but five growing seasons remaining in which to make necessary changes in pest control procedures, there is still some question about the levels of tolerances and exemptions to tolerances. If the international trade of tobacco is to continue, it seems appropriate that by early 1973, there should be provided a list of tolerances which will accurately reflect requirements for the 1978 course of action so that growers can take appropriate action. Consumer protection from proven hazards is a necessary goal in the crowded, environmentally conscious world of today, but restrictions on use of pesticides should not be prohibitively stringent where proper evidence does not justify such action.

\section{ZUSAMMENFASSUNG}

In den letzten Jahren wurden in dem Bemühen, die Rückstände einer Reihe von Pflanzenschutzmitteln in Tabak zu verringern, gute Fortschritte erzielt. In wichtigen Fragen - u. a. vor allem hinsichtlich der notwendigen Änderung noch schwebender gesetzlicher Verordnungen - ist man aber noch nicht zu Lösungen gekommen. Die CORESTA (Cooperation Centre for Scientific Research Relative to Tobacco) und andere europäische und nordamerikanische Interessengruppen haben die Problematik den gesetzgebenden Behörden gegenüber verantwortungsbewußt definiert. Für die notwendigen Änderungen in der Praxis der Schädlingsbekämpfung verbleiben nur fünf Anbauperioden; dennoch bestehen Fragen hinsichtlich der Toleranzwerte und der Ausnahmen davon. Wenn der internationale Tabakhandel weiterhin bestehen soll, ist es zweckmäßig, bis Anfang 1973 eine Liste von Toleranzwerten $z \mathfrak{u}$ erstellen, in der die im Jahre 1978 geltenden Erfordernisse genau festgelegt sind, so daB der Tabakanbau sich darauf einstellen kann. Der Schutz des Verbrauchers vor echten Gefährdungen ist ein notwendiges Anliegen aller umweltbewußten Menschen; die Anwendung von Pflanzenschutzmitteln sollte aber nicht dort einer strengen Beschränkung unterworfen werden, wo das vorliegende Beweismaterial einen derartigen Schritt nicht rechtfertigt.

\section{RESUME}

Durant les dernières années, beaucoup de progrès ont été faits en vue de diminuer les résidus de pesticides sur le tabac. D'importants problèmes n'ont cependant 
pas été résolus. Parmi ceux-ci, certains changements nécessaires à la législation prévue des seuils de tolérance. Le CORESTA et d'autres intérêts du tabac en Europe et en Amérique du Nord ont défini les problèmes pour les législateurs. Alors qu'il ne reste plus que cing saisons de culture, pendant lesquelles il est nécessaire de changer la procédure des contrôles de pesticides, on discute des seuils de tolérance et des exceptions à ces tolérances. Si le commerce international du tabac est appelé à se maintenir, il serait utile de publier au début de 1973 une liste de tolérances, reflètant de façon précise les exigences de 1978 , afin de permettre aux planteurs de prendre les dispositions nécessaires. Dans le monde actuel, surpeuplé et conscient de son environnement, c'est un but nécessaire que de protéger les consommateurs là où le danger de contamination est prouvé, mais l'usage des pesticides ne devrait pas être prohibitivement restreignant lorsqu'aucune preuve ne justifie une telle action.

\section{REFERENCES}

1. Alford, H. G.: Methomyl residues; Environmental Protection Agency, Washington, D. C., private communication (1972).

2. Anonymous: Resolution to restrict chlorinated hydrocarbon insecticides by Entomology Section, Tobacco Workers' Conference, Columbus, Ohio, 1964.

3. Anonymous: Bundesgesetzblatt Nr. 53, Teil I, Z 1997A, ausgegeben zu Bonn am 10. Dezember 1966, p. 665, amended Jan. 18, 1972.

4. Anonymous: Notification on ethylene bisdithiocarbamate fungicides; Environmental Protection Agency, Washington, D. C., March 15, 7972.

5. Anonymous: Residues from pest control agents in tobacco and in tobacco smoke; Wissenschaftliche Forschungsstelle im Verband der Cigarettenindustrie, Hamburg, $197 x$.

6. Burger, J. H., and A. B. Naish: Determination of organochlorine pesticide residues in tobacco and tobacco condensates using a two-column clean-up procedure; 22nd Tob. Work. Conf., Montreal, $\mathrm{Ca}$ nada, 1970 .

7: Campbell, J. S.: Pesticide residues on tobacco for export.; Georgia Tobacco Farmer, May 1971.

8. Carson, R.: Silent spring; Haughton Mifflin Co., Boston, Mass., 368 pp, 1962.

9. Carugno, N., and L. Fedrizzi: Post harvest tobacco treatments; CORESTA Conference, Williamsburg, 1972 . io. Clayson, D. B., C. Biancifiori, U. Milia, and F. E. Gionelli Santilli: The induction of pulmonary tumors in mice by derivative of hydrazine; in: Lung tumours in animals, Proc. of the Third Quadrennial Conf. on Cancer, Univ, of Perugia, June 1965, ed. L. Severi, Division of Cancer Research, Perugia 1966, pp. 869-77.

11. Domanski, J. J., and T. J. Sheets : Insecticide residues on 7970 U.S. auction market tobacco; Tob. Sci. (in press).

12. Domanski, J. J., J. W. Laws, and T. J. Sheets: Insecticide residues on 1971 tobacco products; Tob. Sci. 1973 (in press).

13. Domanski, J. J., and F. E. Guthrie: Insecticide residues in 1972 cigars; Bul. Env. Contam. Toxicol. (in press).

14. French, J. C.: Residues of pesticides on Georgia tobacco; Tobacco Farmer, March 1972.

15. Gibson, J. R., and H. W. Dorough: Insecticide content of burley tobacco; Annual meeting of the Entomological Society of America, Montreal, Canada, 1972.

16. Guthrie, F. E.: The nature and significance of pesticide residues on tobacco and in tobacco smoke; Beitr. Tabakforsch. 4 (1968) 229.

17. Hanson, R. E.: Azodrin residues on tobacco; Shell Chemical Company, San Ramon, California, private communication (1972).

18. Oden, S.: DDT residues in rivers; Agricultural College, Uppsala, Sweden, private communication (1972).

19. Roe, F. J. C., G. A. Grant, and D. M. Millica: Carcinogenicity of hydrazine and 1,1 -dimethylhydrazine for mouse lung; Nature 216 (1967) 375.

20. Sheets, T. J., J. W. Smith, and M. D. Jackson: Pesticide residues in cigarettes; Tob. Sci. 12 (1968) 66.

21. Strictland, P., and E. B. Whitley: Report of 1971 Florida tobacco pesticide residue study; The Fluecured Tobacco Farmer (April 1972).

22. Tappan, W. B., W. B. Wheeler, and.H. W. Lundy: Methomyl residues in cigar-wrapper and flue-cured tobacco in Florida ; J. Econ. Ent. (in press).

23. Vickery, L. S.: Soil residues on tobacco; Canadian Dept. Agriculture, Delhi, Ontario, private communication (1972).

The author's address:

North Carolina State University, School of Agriculture and Life Sciences, Department of Entomology, Box 5215, ZIP 27607, Raleigh, N. C., USA. 